\title{
Kepemimpinan Transformasional Kepala Sekolah Dalam Meningkatkan Mutu Pendidikan SDI Nurul Yaqin Kapedi Bluto Sumenep
}

\author{
Sofianti Nafsiah, Jauharotul Makniyah \\ Institut Dirosat islamiyah Al-Amien Prenduan Sumenep \\ sofiantinafsiah@gmail.com, Jauharah@idia.ac.id
}

\begin{abstract}
Abstrak: Tujuan penelitian ini ingin mengetahui kepemimpinan transformasional kepala sekolah dalam meningkatkan mutu pendidikan, yang dijabarkan menjadi tiga fokus yaitu untuk mengetahui upaya kepala sekolah mengimplementasikan kepemimpinan transformasional dalam meningkatkan mutu pendidikan di SDI Nurul Yaqin. Mengetahui faktor pendukung yang membantu kepala sekolah dalam meningkatkan mutu pendidikan di SDI Nurul Yaqin. Mengetahui faktor hambatan yang dihadapi kepala sekolah dalam meningkatkan mutu pendidikan di SDI Nurul Yaqin. Peneliti menggunakan pendekatan kualitatif lapangan. Adapun metode yang digunakan adalah wawancara, observasi, dan dokumentasi. Dari metode ini, peneliti kemudian menganalisis data yang ada, sehingga beberapa menemukan hasil dari data-data tersebut dalam sebuah kesimpulan. Dalam meningkatkan mutu pendidikan di sekolah, kepemimpinan transformasional kepala sekolah berperan penting dan bersifat urgen dalam proses peningkatannya. Kepemimpinan Kepala Sekolah di Sekolah Dasar Islam (SDI) Nurul Yaqin Kapedi Bluto Sumenep sudah bersifat transformasional, hal ini dapat dilihat dari upaya Kepala Sekolah dalam meningkatkan mutu pendidikan di SDI Nurul Yaqin dengan rapat para guru, Pertemuan orientasi bagi guru baru, diskusi dengan para guru, Studi kelompok antar guru, serta seminar guru. Sedangkan Faktor pendukungnya adalah guru respek terhadap kegiatan sekolah dalam kegiatan proses pembelajaran dan juga loyal terhadap kepala sekolah baik disekolah maupun diluar sekolah. Dan faktor penghambatnya adalah ada sebagian guru yang menetang keputusan kepala sekolah serta sarana dan prasarana yang kurang memuaskan.
\end{abstract}

Kata Kunci: Transformasional, Kepala Sekolah, Mutu Pendidikan

Abstract: The purpose of this study is to find out the principal's transformational leadership in improving the quality of education, which is translated into three 


\section{DIROSAT}

Journal of Islamic Studies

Volume 6, No 1 Januari-Juni 2021

ISSN: 2541-1667 (print); 2541-1675 (online)

focuses, namely to find out the principal's efforts to implement transformational leadership in improving the quality of education at SDI Nurul Yaqin. Knowing the supporting factors that help the principal in improving the quality of education at SDI Nurul Yaqin. Knowing the obstacles faced by school principals in improving the quality of education at SDI Nurul Yaqin. The researcher used a field qualitative approach. The methods used are interviews, observation, and documentation. From this method, the researcher then analyzes the existing data, so that some find the results from these data in a conclusion. In improving the quality of education in schools, the principal's transformational leadership plays an important and urgent role in the improvement process. The leadership of the Principal at the Nurul Yaqin Islamic Elementary School (SDI) Kapedi Bluto Sumenep has been transformational, this can be seen from the Principal's efforts to improve the quality of education at SDI Nurul Yaqin with teacher meetings, orientation meetings for new teachers, discussions with teachers, Study groups between teachers, as well as teacher seminars. While the supporting factors are teachers respect for school activities in the learning process activities and are also loyal to school principals both at school and outside school. And the inhibiting factor is that there are some teachers who oppose the principal's decision as well as unsatisfactory facilities and infrastructure.

Keywords: Transformational, School Leader, Quality of Education

\section{Pendahuluan}

Lembaga pendidikan kini berhadapan dengan derasnya arus perubahan akibat globalisasi yang memunculkan persaingan dalam pengelolaan lembaga pendidikan, baik negeri maupun swasta. Globalisasi menuntut perlunya relevansi program sekolah dengan kebutuhan masyarakat dan dunia kerja/industri terhadap mutu lulusan (out-put) serta munculnya globalisasi pendidikan dengan bermunculannya lembaga pendidikan yang bertaraf internasional. ${ }^{1}$

Pendidikan adalah karya bersama yang berlangsung dalam suatu pola kehidupan insani tertentu. Menurut Webster's New World Dictionary pendidikan adalah "proses pelatihan dan pengembangan pengetahuan, keterampilan, pikiran, karakter, dan seterusnya, khususnya lewat persekolahan formal”. Pemahaman mengenai pendidikan mengacu pada konsep tersebut menggambarkan bahwa pendidikan memiliki sifat dan sasarannya yaitu manusia. Manusia itu sendiri mengandung banyak aspek dan sifatnya yang sangat kompleks. Karena itu tidak ada suatu batasan yang cukup memadai untuk menjelaskan arti pendidikan secara lengkap. Batasan pendidikan yang dibuat para ahli tampak begitu beraneka ragam, dan kandungannya berbeda antara satu dari yang lain. ${ }^{2}$

Banyak faktor yang mempengaruhi dunia pendidikan di antaranya adalah kepemimpinan yang dipraktekkan oleh seorang Kepala Sekolah, Seorang Kepala Sekolah adalah pemimpin pada suatu lembaga satuan pendidikan. Kepala sekolah ialah pemimpin yang proses kehadirannya dapat dipilih secara langsung, ditetapkan

\footnotetext{
${ }^{1}$ Suyatno, Manajemen Strategik dalam Pendidikan,( Jakarta: Media Pusindo, 2011), h.1.

${ }^{2}$ Syaiful Sagala, Manajemen Strategik dalam Peningkatan Mutu Pendidikan, (Bandung: Alfabeta, CV, 2010), h.1.
} 


\section{DIROSAT}

Journal of Islamic Studies

Volume 6, No 1 Januari-Juni 2021

ISSN: 2541-1667 (print); 2541-1675 (online)

oleh yayasan, atau ditetapkan oleh pemerintah. ${ }^{3}$

Kepemimpinan merupakan salah satu unsur yang menentukan dalam keberlangsungan dan perkembangan organisasi termasuk organisasi pendidikan. Di zaman yang terus mengalami perubahan dan perkembangan seperti sekarang ini, kepemimpinan yang peka terhadap perubahan dan perkembangan akan diperlukan dalam memberdayakan semua potensi yang dimiliki organisasi tersebut. Kepemimpinan yang demikian diperlukan dalam mendorong organisasi untuk terus belajar dan tanggap terhadap perubahan dan perkembangan yang terjadi serta semakin berusaha dalam meningkatkan performa organisasinya. Demikian pula sekolah, sebagai suatu organisasi yang terus belajar dalam pengertian dinamis dan tanggap terhadap perkembangan ilmu dan teknologi semakin membutuhkan kepemimpinan yang dapat menjawab tantangan, pembaharuan dan aspirasi terhadap perubahan yang terjadi.

Manajemen Berbasis Sekolah menekankan keterlibatan tinggi (high involvement model) dari orangtua dan masyarakat yang sering dilakukan oleh sekolah swasta, salah satunya adalah Sekolah Dasar Islam Nurul Yaqin Kapedi. Di mana ketergantungan langsung sekolah dengan pemerintah sangat rendah tentunya dengan tidak mengabaikan kebijakan nasional. Sekolah swasta lebih beroriesntasi pada kemampuan yang memungkinkan keterlibatan orangtua dan masyarakat secara bermakna dalam melaksanakan kegiatan sehingga sekolah menjadi lebih mandiri.

Berdasarkan observasi yang dilakukan di lapangan, Sekolah Dasar Islam Nurul Yaqin (SDINY) merupakan satuan pendidikan dasar yang menyelenggarakan program pendidikan 6 tahun berdasarkan kurikulum nasional dan diperkaya dengan pendidikan Islam (integral learning). Pendekatan integral (integral learning) pada dasarnya berupaya memadukan aspek kurikulum, proses pembelajaran, metode serta tujuan. Sedangkan kurikulum Islam Nurul Yaqin yang diterapkan, berupaya memadukan kurikulum Diknas, Depag dan ciri khas lembaga yang selanjutnya direalisasikan dalam proses pembelajaran. Di mana dalam lembaga ini berorientasi pada tujuan (membentuk generasi yang mandiri dan Robbani), berorientasi pada proses (tumbuhnya kesadaran untuk selalu melakukan proses perubahan), belajar sambil bermain (optimalisasi potensi kognitif dan psikomotorik). Dengan pembelajaran seperti ini, diharapkan pada akhirnya anak akan tumbuh kecerdasan intelektual, emosional dan spiritual (IESQ).

Sekolah Dasar Islam Nurul Yaqin adalah sebuah lembaga di bawah Lembaga Pendidikan Islam Nurul Yaqin. Dengan demikian ada sebuah karakter khusus yang harus diperhatikan dalam menciptakan sistem manajerial yang tepat bagi sebuah lembaga pendidikan. Komponen utama yang ada dalam sebuah lembaga pendidikan yakni sumber daya manusia dan konseptual (kurikulum). Sedangkan komponen sarana prasarana tidak lebih sebagai komponen pendukung. Dalam artian, yang berpengaruh besar terhadap perkembangan sebuah lembaga pendidikan adalah komponen SDM dan kurikulumnya. Dengan demikian diperlukan sistem manajerial yang mampu memberikan kesempatan terhadap kedua komponen ini agar

\footnotetext{
${ }^{3}$ Jamal Ma'mur Asmani, Tips Menjadi Kepala Sekolah Profesional,( DIVA Press), h.16.
} 


\section{DIROSAT}

Journal of Islamic Studies

Volume 6, No 1 Januari-Juni 2021

ISSN: 2541-1667 (print); 2541-1675 (online)

berkembang secara optimal, sekaligus mampu bergerak dinamis mengikuti perkembangan zaman.

Pada hakikatnya keberhasilan pelaksanaan pendidikan di suatu sekolah tidak hanya diukur dari jumlah lulusannya saja, tetapi juga tingkat belajar siswa dan kinerja seluruh komponen sistem sekolah dalam rangka meningkatkan efektivitas, efisiensi, produktivitas sekolah dan kualitas kehidupan kerja. Kualitas kehidupan kerja dengan iklim yang baik akan memungkinkan tenaga pendidik bekerja dengan tenang dan nyaman yang pada akhirnya dapat meningkatkan motivasi mereka dalam bekerja sehingga dapat menyumbangkan kinerja yang optimal.

Dalam perannya sebagai top manager, Kepala Sekolah bertugas menyusun program, menyusun pengorganisasian sekolah, menggerakkan staf, mengoptimalkan sumber daya sekolah dan mengendalikan kegiatan sebagai administrator, Kepala Sekolah bertugas mengelola administrasi, kegiatan mengajar belajar dan bimbingan konseling, kesiswaan, ketenagaan, keuangan, sarana dan prasarana, persuratan serta urusan rumah tangga sekolah sebagai pemimpin, Kepala Sekolah bertugas menyusun dan mensosialisasikan visi dan misi suatu program sekolah, mengambil keputusan dan melakukan komunikasi sebagai pembaharu (inovator).

Kepemimpinan transformasional tidak saja didasarkan kebutuhan akan penghargaan diri, tetapi menumbuhkan kesadaran pada pemimpin untuk berbuat yang terbaik dengan kajian perkembangan manajemen dan kepemimpinan yang memandang manusia, kinerja dan pertumbuhan organisasi adalah sisi yang saling berpengaruh. Dengan demikian, jika dikaitkan dengan penjelasan di awal dalam tuntutan desentralisasi pendidikan, maka kepala sekolah dipandang perlu untuk menerapkan kepemimpinan transformasional.

Kepemimpinan transformasional merupakan alternatif kepemimpinan yang dapat diterapkan di sekolah untuk menjawab tantangan pembaharuan dan aspirasi terhadap perubahan yang terjadi di sekolah, baik secara eksternal maupun internal. Seperti yang diungkapkan oleh Bass dan Avolio dalam Raihani terdapat lima faktor dalam kepemimpinan transformasional yang meliputi atribut-atribut yang ideal, yaitu mengacu pada pemimpin yang bertindak sebagai model yang kuat untuk pengikutnya. perilaku yang ideal, yaitu mengacu pada tingkat sejauh mana pemimpin menunjukkan perilaku yang mendorong rekan kerjanya agar memiliki visi dan tujuan yang sama. motivasi inspiratif, mengacu kepada seorang pemimpin yang mengkomunikasikan harapan-harapan yang tinggi kepada pengikutnya. stimulasi intelektual, yaitu perilaku seorang pemimpin yang menstimulasi bawahannya agar kreatif dan inovatif. dan konsiderasi yang diindividualisasikan, yaitu mengacu kepada perilaku seorang pemimpin yang menciptakan suasana di mana kebutuhan-kebutuhan individual pengikut diperhatikan oleh pemimpin. ${ }^{4}$

\section{Metode Penelitian}

Peneliti menggunakan pendekatan kualitatif lapangan dengan maksud untuk memahami fenomena tentang sesuatu hal yang dialami oleh seseorang pada konteks

\footnotetext{
${ }^{4}$ Raihani, Kepemimpinan Sekolah Ttransformatif, (Yogyakarta: LkiS Group,2010), h. 21.
} 


\section{DIROSAT}

alamiah seperti, perilaku, motivasi, tindakan dan lain-lain. Secara deskriptif dalam bentuk bahasa dan kata-kata dengan menggunakan berbagai metode alamiah. ${ }^{5}$. Jenis penelitian ini adalah penelitian kualitatif. Penelitian kualitatif didefinisikan sebagai prosedur penelitian yang menghasilkan data deskriptif berupa kata-kata tertulis atau lisan dari orang-orang dan perilaku yang dapat diamati dengan memaparkan keadaan objek yang diteliti. Penelitian ini digunakan untuk mendeskripsikan tentang segala sesuatu yang berkaitan dengan kepemimpinan transformasional kepala sekolah dalam meningkatkan mutu pendidikan di SDI Nurul Yaqin.

Pendekatan penelitian yang digunakan dalam skripsi ini adalah pendekatan kualitatif metode dekriptif, metode ini dapat diartikan sebagai prosedur pemecahan masalah yang diselidiki dengan menggambarkan keadaan objek penelitian pada saat sekarang berdasarkan fakta-fakta atau apa adanya, metode deskriptif memusatkan perhatiannya pada menemukan fakta-fakta sebagaimana keadaan sebenarnya. ${ }^{6}$

Pendekatan penelitian kualitatif adalah proses penelitian yang menghasilkan data deskriptif berupa kata-kata tertulis atau lisan dari orang-orang dan prilaku yang dapat diamati. Oleh karena itu, penelitian ini menggunakan metode deskriptif. Jadi jenis penelitian ini memahami pendekatan kualitatif karena melalui pendekatan tersebut lebih tepat untuk mengidentifikasikan kepemimpinan transformasional kepala sekolah dalam meningkatkan mutu pendidikan di SDI Nurul Yaqin.

\section{Hasil Dan Pembahasan}

Upaya Kepala Sekolah Mengimplementasikan Kepemimpinan Transformasional dalam Meningkatkan Mutu Pendidikan Di SDI Nurul Yaqin: Mengadakan Rapat Guru, Tujuannya untuk menyatukan guru, mendorong guruguru untuk melaksanakan tugas-tugasnya dengan baik, menyatukan pendapatpendapat guru.

Pertemuan Orientasi Bagi Guru Baru Tujuannya memberikan informasi perkenalan kepada guru baru terhadap sistem kerja dari sekolah dengan melalui percakapan bersama diselingi dengan diskusi bersama. Diskusi dengan Guru-Guru, Melakukan pertukaran pendapat tentang suatu masalah untuk mengembangkan keterampilan para guru dalam mengatasi kesulitan-kesulitan yang mereka hadapi bersama. Melalui diskusi, guru-guru merasa turut bertanggung jawab dan berpartisipasi dalam mengemukakan pendapat mereka masing-masing.

Studi Kelompok antar Guru

Kelompok guru yang mengajar mata pelajaran yang sejenis, dan membahas atau mendalami bahan pelajaran yang mereka ajarkan. Perencanaan studi ini harus dipersiapkan secara matang dan terperinci mengenai berbagai masalah yang akan dibicarakan. Seminar Guru, Seminar guru SDI Nurul Yaqin biasanya ikut di sumenep dan hanya salah satu yang di utus kemudian hasilnya di laporkan, di diskusikan bersama dan di terapkan.

Faktor yang Membantu Kepala Sekolah dalam Meningkatkan Mutu Pendidikan

\footnotetext{
${ }^{5}$ Lexy Moeleng, Metodologi Penelitian Kualitatif, (Bandung: 2007) h. 6

6 Ibid, h. 14.
} 


\section{DIROSAT}

Journal of Islamic Studies

Volume 6, No 1 Januari-Juni 2021

ISSN: 2541-1667 (print); 2541-1675 (online)

Di SDI Nurul Yaqin: Guru respek terhadap kegiatan sekolah, Guru loyal terhadap kepala sekolah, Guru selalu membantu kepala sekolah, Daya dukung atau kerja sama masyarakat.

Faktor Hambatan yang Dihadapi Kepala Sekolah dalam Meningkatkan Mutu Pendidikan Di SDI Nurul Yaqin. Ada sebagian guru yang menentang keputusan kepala sekolah. Guru tidak merespon dengan baik atas teguran yang dilayangkan oleh kepala sekolah. Sarana dan prasarana kurang memuaskan, dan Keterampilan guru sangat minim.

Kepemimpinan merupakan kumpulan kualitas intelektual seseorang yang digunakan untuk mempengaruhi, memotivasi, dan mengarahkan orang lain baik secara individual maupun kelompok serta mampu memfasilitasi dengan cara mengkoordinasi segala tugas yang telah ditetapkan sebelumnya untuk mencapai tujuan bersama dengan sebaik-baiknya. Dengan demikian terdapat nilai implikasi yakni: kepemimpinan itu memerlukan kemampuan intelektual untuk mengelola segala tugas yang telah ditetapkan sebelumnya untuk mencapai tujuan bersama dan kepemimpinan memerlukan kemampuan untuk mengkoordinasi, memfasilitasi, memberikan motivasi dan arahan kepada pegawai baik secara individual atau kelompok. Dalam dunia pendidikan, pelaksanaan proses mengajarbelajar di sekolah akan berjalan dengan baik apabila Kepala Sekolah selaku pemimpin dapat membagi tugas guru-guru yang dipimpinnya secara proporsional. ${ }^{7}$

Kepemimpinan transformasional adalah sebuah proses dimana pemimpin mengambil tindakan-tindakan untuk meningkatkan kesadaran rekan kerja mereka tentang apa yang benar dan apa yang penting, untuk meningkatkan kematangan motivasi rekan kerja mereka serta mendorong mereka untuk melampaui minat pribadi mereka demi mencapai kemaslahatan kelompok, organisasi, atau masyarakat. 8

Sejauh mana pemimpin dikatakan sebagai pemimpin transformasional, hal tersebut dapat diukur dalam hubungannya dengan pengaruh pemimpin tersebut terhadap pegawai. Oleh karena itu, ada tiga cara seorang pemimpin transformasional memotivasi pegawai, yaitu dengan: Mendorong pegawai untuk lebih menyadari arti penting hasil usaha, Mendorong pegawai untuk mendahulukan kepentingan kelompok. Dan Meningkatkan kebutuhan pegawai yang lebih tinggi seperti harga diri dan aktualisasi diri. ${ }^{9}$

Jadi dapat ditarik kesimpulan bahwa kepemimpinan transformasional adalah seorang pemimpin yang mempunyai keahlian mendiagnosis, selalu meluangkan waktu dan mencurahkan perhatian dalam upaya untuk memecahkan masalah dari berbagai aspek. Menurut Mulyasa pengertian kepala sekolah adalah salah satu komponen pendidikan yang saling berperan dalam meningkatkan kualitas pendidikan. Kepala sekolah adalah penanggung jawab atas penyelenggaraan pedidikan, administrasi sekolah, pembinaan tenaga pendidikan administrasi

\footnotetext{
${ }^{7}$ Komariah, Aan dan Cepi Triatna, Visionary Leadership Menuju Sekolah Efektif . (Jakarta: Bumi Aksara, 2005), h.75

8 Ibid., h. 20.

${ }^{9}$ Danim, Sudarwan, Kepemimpinan Transformasional dalam Komunitas Organisasi Pembelajaran (cet. 2), (Jakarta: Bumi Aksara), h.155.
} 


\section{DIROSAT}

Journal of Islamic Studies

Volume 6, No 1 Januari-Juni 2021

ISSN: 2541-1667 (print); 2541-1675 (online)

sekolah, pembinaan tenaga pendidikan lainnya, pendayagunaan serta pemeliharaan sarana dan pra sarana juga sebagai supervisor pada sekolah yang dipimpinnya. ${ }^{10}$

Pengertian mutu adalah keunggulan suatu produk baik berupa barang maupun jasa yang memuaskan, memenuhi keinginan pelanggan dan kebutuhan pelanggan. Dalam konteks pendidikan pengertian mutu. ${ }^{11}$ Mutu pendidikan ialah kecocokan dengan kebutuhan. Dan juga mutu adalah konsep yang absolut dan relatif. Mutu yang absolut adalah mutu yang mempunyai idealisme tinggi dan berstandar tinggi yang harus dipenuhi, dengan sifat produk bergengsi yang tinggi. Sedangkan mutu relatif adalah sebuah alat yang sudah ditetapkan dan harus memenuhi standar yang telah dibuat. ${ }^{12}$

Jadi mutu pendidikan adalah usaha terprogram/tersistem, sinergis, kontinyu, berproses secara kompleks, holistik, dan konsisten. Terprogram dimaknai, bahwa lembaga pendidikan memiliki tujuan yang diterjemahkan dalam visi, misi, langkah strategis. Secara konseptual, tujuan tadi diterjemahkan dan diimplementasikan dalam seluruh aspek kegiatan lembaga tersebut, sampai tujuannya terwujud ideal. Sinergis dimaknai, terpadunya dan terkonsentrasikannya seluruh kekuatan dan elemen pendukung untuk secara bersama-sama memberdayakan diri sehingga tujuan lembaga tersebut terwujud secara ideal pada tahapan waktu yang ditentukan. Kontinyu, menunjuk makna bahwa usaha mengukir tujuan dan mutu pendidikan tadi dijalankan dari waktu ke waktu, proses ke proses, langkah demi langkah, tahapan demi tahapan, pencapaian tingkat tertentu ke tingkat yang lebih tinggi, sehingga terbentuk kurva meningkat ideal. Ini perlu perjuangan, ketelitian, kejelian, kesabaran, keuletan, ketangguhan, dan optimisme.

\section{Kesimpulan}

Setalah peneliti mengalisis dari semua pembahasan dalam penelitian ini, maka peneliti mengambil kesimpulan sebagai berikut: Kepemimpinan Kepala Sekolah di Sekolah Dasar Islam (SDI) Nurul Yaqin Kapedi Bluto Sumenep sudah bersifat transformasional, hal ini dapat dilihat dari upaya Kepala Sekolah dalam meningkatkan mutu pendidikan di SDI Nurul Yaqin dengan rapat para guru, Pertemuan orientasi bagi guru baru, diskusi dengan para guru, Studi kelompok antar guru, serta seminar guru. Karena seorang pemimpin dikatakan bergaya transformasional apabila dapat mengubah situasi, mengubah apa yang biasa dilakukan, bicara tentang tujuan yang luhur, memiliki acuan nilai kebebasan, keadilan dan kesamaan.

Faktor pendukung dari upaya peningkatan kepemimpinan transformasional kepala sekolah dalam meningkatkan mutu pendidikan di SDI Nurul Yaqin adalah guru respek terhadap kegiatan sekolah dalam kegiatan proses pembelajaran di SDI Nurul Yaqin, Guru loyal terhadap kepala sekolah baik disekolah maupun diluar sekolah. Dan yang terakhir adalah guru selalu membantu kepala sekolah dalam

\footnotetext{
10 Mulyasa, Menjadi Guru Profesional (Bandung : Rosda Karya, 2007), h. 24

11 Suderadjat, Hari, Manajemen Peningkatan Mutu Berbasis Sekolah: Peningkatan Mutu Pendidikan Melalui Implementasi KBK, (Bandung : Cipta Lekas Garafika, 2005), h. 65

12 Ibid., h. 80-83
} 
semua kegiatan yang ada di sekolah.

Sedangkan faktor penghambat dari upaya peningkatan kepemimpinan transformasional kepala sekolah dalam meningkatkan mutu pendidikan di SDI Nurul Yaqin adalah ada sebagian guru yang menetang keputusan kepala sekolah. Bersikeras tidak mau menjalankan dengan sepenuhnya, ada juga sebagian guru tidak merespon dengan baik atas teguran yang dilayangkan oleh kepala sekolah dan malah menentang. Kemudian Sarana dan prasarana kurang memuaskan baik untuk kegiatan kurikuler dan ekstra-kurikuler, kemudian keterampilan guru di SDI Nurul Yaqin masih kurang.

\section{Daftar Pustaka}

Al-Qur'an terjemah Al-Jumanatul Ali. Bandung: CV. Penerbit J-ART, 2005

Asmani,Jamal Ma'mur, Tips Menjadi Kepala Sekolah Profesional. DIVA Press, 2012

Arikunto Suharsimi, Prosedur Penelitian Suatu Pendekatan Praktik. Jakarta: PT Rineka Cipta, 2006

Buna'i, Penelitian Kualitatif. Pamekasan: Press, 2008

Danim, Sudarwan, Kepemimpinan Transformasional dalam Komunitas Organisasi Pembelajaran (cet. 2). Jakarta: Bumi Aksara, 2005.

Depdikbud. Kamus Besar Bahasa Indonesia. Jakarta. PN. Balai Pustaka, 1992.

Dhofier Syarqowi, Pengantar Metodologi Riset dalam Perspektrum Islam. Sumenep: Sari Safir, 1999

Komariah, Aan dan Cepi Triatna, Visionary Leadership Menuju Sekolah Efektif. Jakarta: Bumi Aksara, 2005.

Kartono Kartini, Pemimpin Dan Kepemimpinan. Jakarta: PT Raja Grafindo Persada, 2011

Moeleong Lexy, Metodologi Penelitian Kualitatif. Bandung: 2007

Moerdiyanto, Strategi Pelaksanaan Sistem Penjaminan Mutu Pendidikan (SPPMP)

Oleh Pemerintah Kabupaten/Kota, UNY, 2009

Morrow Stephen C., Leadership, Not Salesmanship. America: Xulon Press, 2002

Mulyasa, Menjadi Guru Profesional Bandung : Rosda Karya, 2007

Norboho, Nor Cholid dan Abu Ahmadi, Metodelogi Penelitian. Bandung: Pustaka

Setia, 1998

Raihani, Kepemimpinan sekolah transformatif. Yogyakarta: LkiS Group, 2010

Rusli Mohammad \& El-Qaderie Hisyam, Metode Penelitian Kuantitatif dan Kualitatif Berorientasi Praktis. Sumenep: LP3m paramadani, 2013

Sagala, Syaiful. Manajemen Strategik dalam Peningkatan Mutu Pendidikan. Bandung: Alfabeta, CV, 2010.

Suderadjat, Hari, Manajemen Peningkatan Mutu Berbasis Sekolah: Peningkatan Mutu Pendidikan Melalui Implementasi KBK, Bandung : Cipta Lekas Garafika, 2005.

Sa'ud Udin Syaefudin dan Abin Syamsudin Makmun, Perencanaan pendidikan. Bandung: PT Remaja Rosdakarya. 2011

Sukardi, Metodologi Penelitian Pendidikan Kompetensi dan Prakteknya, Jakarta:

Bumi Aksara, 2003

Suprihatin dkk, Manajeman Sekolah. Semarang: Unnes Press, 2004. 
Suyatno. Manajemen Strategik dalam Pendidikan. Jakarta: Media Pusindo, 2011. Shelton Edrward J., Transformational Leadership, North America: Trafford, 2012 Wilmore Elaine L., Principal Leadership California: Corwin Press INC, 2010 